\title{
A new source of omega-3 and gamma tocopherol: Fig (Ficus carica L.) seed oil
}

\section{Yeni bir omega-3 ve gama tokoferol kaynağı: incir (Ficus carica L.) çekirdeği yağı}

\author{
Sultan TARLACI ${ }^{1 *}$ (D) \\ 1*Üsküdar Üniversitesi, Tıp Fakültesi, NP İstanbul Beyin hastanesi, İstanbul
}

${ }^{1}$ https://orcid.org/0000-0001-7634-1467

\section{To cite this article:}

Tarlacı, S. (2021). A new source of omega-3 and gamma tocopherol: fig (Ficus carica L.) seed oil. Harran Tarım ve Gıda Bilimleri Dergisi, 25(4):

*Address for Correspondence: Sultan TARLACI

e-mail:

tarlacisultan@gmail.com

Received Date:

06.10 .2020

Accepted Date:

25.11.2021

(C) Copyright 2018 by Harran University Faculty of Agriculture. Available on-line at www.dergipark.gov.tr/harranziraat

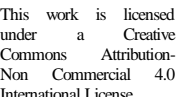

\section{ABSTRACT}

Essential fatty acids are oils which cannot be synthesized in the human body and which must be acquired from elsewhere. The omega- 3 family is a wide group, the most important and commonest of which are alpha-linoleic acid, stearidonic acid, eicosatetraenoic acid, eicosapentaenoic acid, and docosahexaenoic asit. On the orther side, vitamin $E$ is one of the most important antioxidants in humans. Vitamin $E$ forms two main families, alpha, beta, gamma and delta tocopherol, and tocotrienol. For this study, fig seeds separated and oils obtained by cold press from the seeds of Ficus carica has been analyzed. Obtained oil acid content was analyzed by the gas chromatography with flame-ionization detection method. The High-Performance Chromatography Fluorescence Detector (HPLC-FLD) method was used to measure levels of vitamin E tocopherol. According to the results of the analysis, Ficus carica seed oil was seen to be rich in linolenic acid (omega-3, 40,25\%), linoleic acid (omega-6, $31,28 \%$ ), and oleic acid (omega-9, 17,0\%) and it contained smaller amounts of palmitic acid, and other oils in trace amounts. Aflatoxin was not detected in the obteined seed oil. Ficus carica seed oil was found to have a high content of gamma tocopherol proportion $(4090,70 \pm$ $383,30 \mathrm{mg} / \mathrm{kg}$ ) is compared with that of other edible oil sources.

Key Words: Omega-3, Vitamin E, Essential fatty acids, Gamma tocopherol, Fig seeds oil, Ficus carica

Öz

Esansiyel yağ asitleri normalde insan bedeninde sentezlenemezler ve dışarıdan alınmaları zorunludur. Omega-3 ailesi geniş bir gruptur ve en önemli ve en yaygın olanları alfa linoleik asit, steraidonik asit, eikosatetraenoik asit, eikosapentaenoik asit ve dokosaheksaenoik asittir. Vitamin $E$ insanlarda en önemli antioksidandır ve yağların peroksidasyonu etki mekanizmasıdır. Vitamin E formları alfa, beta, gamma ve delta tokoferol ile tokotrienol olarak iki temel ailedir. Bu araştırma için, Ficus carica'nın çekirdeklerinden soğuk sıkım yolu ile yağ içeriği elde edildi. Elde edilen yağ içeriği alev-iyonizasyon metodu kullanılarak ile gaz kromotografisi ile analiz edildi ve aynı zamanda vitamin E oranları ölçüldü ve bunun için HPLCFLC metodu kullanıldı. Analiz sonuçlarına göre, Ficus carica çekirdek yağı linolenik asit (omega$3, \% 40,2$ ), linoleik asit (omega-6, \%31,2) ve oleik asitten (omega-9, \%17,0) zengindir ve az miktarda palmitik asit $(\% 7,3)$, eser miktarda diğer yağları içermektedir. Aynı zamanda Ficus carica çekirdek yağında yüksek oranda, 100 g'da $391 \mathrm{mg}$ gama tokoferol bulundu ve elde edilen ürünün aflatoksin içermediği tespit edildi. Analizde ortaya çıkan bu içerikler göz önüne alındığında, diğer yenilebilir yağlarla karşılaştırıldığında, Ficus carica çekirdek yağı yüksek oranda gama tokoferol ve omega-3 içermektedir.

Anahtar Kelimeler: Omega-3, Vitamin E, Esansiyel yağ asitleri, Gama tokoferol, İncir çekirdeği yağı, Ficus carica 


\section{Introduction}

Essential fatty acids are oils which cannot be synthesized in the body and which must be acquired from elsewhere. In humans, only two fatty acids are essential: alpha linolenic acid (ALA) and linoleic acid (LA) (Whitney and Rolfes, 2008). ALA is an omega- 3 fatty acid and LA is an omega- 6 fatty acid. Some other fatty acids are accepted as essential in conditions of development or illness, for example DHA (docosahexaenoic acid) and gamma-linolenic acid

The omega- 3 family is a wide group, the most important and commonest of which are alphalinoleic acid (18:3), stearidonic acid (18:4), eicosatetraenoic acid (20:4), eicosapentaenoic acid (EFA, 20:5), and docosahexaenoic asit (DHA, 22:6). Omega-6 fats are hard and dense. According to some researchers, what is important is not how much omega-3 we eat, but how much we eat in comparison to our consumption of omega-6 (Simopoulos, 2002). Saturated omega-6 oils, unlike omega-3, are pro-inflammatory. Omega-6 oils lead the formation of prostaglandin, leukotriene and cytokines. These substances cause inflammation on the body or in the brain (Simopoulos, 2010).

Vitamin $E$ is an important antioxidant which is soluble in oil and has important antioxidant functions in lipoproteins especially in cell membranes. Vitamin $E$ is one of the most important antioxidants in humans, and its effect mechanism is lipid peroxidation. Lipid peroxidation is particularly widespread in cell and organelle membranes, in lipoproteins, in fatty tissue, in the brain and in other tissues where polyunsaturated fatty acids are plentiful (Sydenham et al., 2012). The vitamin E family consists of seven molecules which are different but related to each other. Vitamin $E$ forms two main families, alpha, beta, gamma and delta tocopherol, and tocotrienol (Nada, 2011). The pharmacological, phytochemical and antioxidant properties of ficus carica, fig seed oil have been demonstrated by various studies in the world (Joseph, 2011; Mawa, 2013; Badgujar, 2014) and in the Turkey (Güven, 2019). It has been found to be very rich in essential fatty acids and vitamin $\mathrm{E}$. The aim of this study is to make an additional contribution to this literature from our country sample.

\section{Materials and Methods}

Because fig seeds are very small, it is not possible to benefit from their nutrient content by chewing or eating them. They generally pass through the body and are passed out without digestion. Seeds of the species Ficus carica (common fig), which is the species grown in the Aegean region, contain fruit or other material. As far as we know, the seeds of Ficus carica have not been isolated and the oil obtained from them has not previously been analyzed. In this study, fresh figs grown in three different locations (Aegean region, Incirliova, Kuyucak, Nazilli) were obtained. The method of obtaining fig seeds was the first to obtain oil from the seeds of Ficus carica in a pure form. First, dried figs are washed to remove dust and dirt. After removing moisture, the figs are reduced to pieces of less than $5 \mathrm{~mm}$ in size. The resulting material is left to soak. The seeds are then separated from the flesh by many washing, sedimentation and drying, and the separated seeds are allowed to dry naturally. The obtained fig seeds were stored at $4{ }^{\circ} \mathrm{C}$ until analysis. Oil from Ficus carica seeds was obtained by cold press method (KYP-10, Cold Pres) without heat process in environments not exceeding $30^{\circ} \mathrm{C}$. During the research, appproximately $24 \mathrm{~kg}$ of dried figs gives about $1 \mathrm{~kg}$ of seeds, and $1 \mathrm{~kg}$ of seeds provides 200 cc of seed oil.

The oil obtained by cold press from the seeds of Ficus carica has been analyzed at the Food Analysis Laboratories of the Drug Development and Pharmokinetics Research and Application Center in Ege University. The High-Performance Chromatography Fluorescence Detector (HPLCFLD) method was used to measure levels of vitamin $E$ tocopherol. In this way, total vitamin $E$ values and alpha, beta, gamma and delta tocopherol contents were measured by 
fluorescent detector liquid chromatography. However, tocotriol levels were not measured in this study. Fatty acid content was analyzed by the Gas Chromatography with Flame-Ionization Detection (GC-FID) method. This is an important and well-established method of analyzing omega3 and 6 fatty acids (Alinafiah, 2021). In addition, aflatoxin analysis was performed on the final product.

\section{Results and Discussion}

According to the results of the analysis, Ficus carica seed oil was seen to be rich in linolenic acid (C18:3), linoleic acid (C18:2), and oleic acid (C18:1). It contained smaller amounts of palmitic acid (C16:0), and other oils in trace amounts. These were caprolic acid (C6:0), caprilic acid (C8:0), capric acid (C10:0), undecanoic acid (C11:0), lauric acid (C12:0), tridecanoic acid (C13:0), myristoleic acid (C14:1), cis-10pentadecanoic acid (C15:1), cis-10-heptadecanoic acid (C17:1), arachidic acid (C20:0), heneicosanoic acid (C21:0), euric acid (C22:1n9), tricosanoic acid (C23:0), cis-13, 16, decosadienoic acid (C22:2), punicic acid, cis-5, 8, 11, 14, 17-eicosapentaenoic acid (EPA; C20:5n3), nervonic acid (C24:1), cis-4, 7,10,13,16,19-docosahexaenoic acid (DHA; $\mathrm{C} 22: 6 \mathrm{n} 3)$ and trans oleic acid.

With regard to vitamin $\mathrm{E}$ tocopherol content, Ficus carica seed oil was found to have a high content of gamma tocopherol at $391.89 \pm 0.06$ $\mathrm{mg}$ per $100 \mathrm{~g}$. After gamma tocopherol, delta tocopherol (7.65 $\pm 0.02 \mathrm{mg} / 100 \mathrm{~g})$ and alpha tocopherol (4.60 $\pm 0.01 \mathrm{mg} / 100 \mathrm{~g}$ ) were found at the highest levels, but beta tocopherol was not found.

Seen from all these viewpoints, omega-3 sources are important. Mainly, oils obtained from various seeds may contain omega-3. Among these, omega-3 is found in small amounts in canola (rapeseed) oil (omega-6 / omega-3 in a proportion of 2.2), in soya oil (in a proportion of 7.5), and in trace amounts in corn and olive oils. Omega-3 is found in the highest proportions in linseed oil. Sesame, peanut, cottonseed, sunflower and coconut oils do not contain omega3 (Siger, 2008). According to the results, fig seed oil it is important to find new sources of omega-3.

Considering all these benefits, there is a need for new and accessible plant sources of omega-3 and its derivatives alongside that which is obtained from seafoods. In the analysis of Ficus carica seed oil, it is seen that in particular the fatty acids linolenic acid (omega-3, 40\%), linoleic acid (omega-6, 31\%), oleic acid (omega-9, 17\%), and palmitic and stearic acids are dominant. The essential fatty acids linolenic and linoleic acid together constitute $70 \%$ of fig seed fatty acids.

Alpha linolenic acid (ALA) is an omega-3 fatty acid and one of the two essential fatty acids. It is said to be essential because it is necessary for health and it is not produced in the human body, and thus must be included in the diet. It is obtained from nuts and seeds such as walnut oil $(10 \%)$, soya ( $8 \%)$, and linseed. Linoleic acid (LA) is a polyunsaturated omega- 6 fatty acid. It is the other essential fatty acid, along with linolenic acid, and omega-3. It is used in the formation of arachidonic acid and some prostaglandins, leukotrienes (LTA, B, C), and thromboxane. It is found in the structure of cell membranes, and is obtained from many plant seeds such as linseed, sesame, sunflower, corn and soya oils.

Palmitic acid (PA) is the most widely found fatty acid in micro-organisms, plants, animals and humans. It is found in small amounts (7\%) in fig seed oil. PA is also used in industry in soap and cosmetic products (WHO Technical Report Series, 2003). It has been added to some drugs to make them effective for longer (Hunter et al., 2009). Stearic acid (SA) is a saturated fatty acid. It is found in small amounts (3\%) in fig seed oil. It is used in the manufacture of detergents, soaps, and cosmetic products such as shampoos and bath creams. Compared to other saturated fatty acids, SA lowers LDL cholesterol (Senyilmaz et al., 2015; Campbell, 2003).

High proportions of vitamin E and especially gamma tocopherol have been determined in the seed oil of Ficus carica. When this proportion is compared with that of other edible oil sources, 
gamma tocopherol content at a clearly high proportion is seen (Table 1). However, a lot of research finding shown by both experimental and clinical research is that gamma tocopherol may be the most effective of the sub-types of vitamin $E$ (alpha, beta, and delta tochoperol) and also the increasing interest in gamma tocopherol (Hernandez et al., 2004; Campbell et al., 2003; Khanna et al., 2005).

Table 1. Tocopherol levels in various edible vegetable oils (Ong, 1993; Sheppard et al., 1993) and our Ficus carica L. tocopherol results for comaprison.

\begin{tabular}{|c|c|c|c|c|c|}
\hline \multicolumn{6}{|c|}{ Tocopherol, mg / $100 \mathrm{~g}$} \\
\hline Oil type & Alpha & Beta & Gamma & Delta & Total \\
\hline Ficus carica & 4.6 & - & 391.88 & 7.65 & 404.13 \\
\hline Canola & 21.0 & 0.1 & 4.2 & 0.04 & 25.34 \\
\hline Castor oil & 2.8 & 2.9 & 11.1 & 31.0 & 47.8 \\
\hline Coconut & 0.5 & - & - & 0.6 & 1.1 \\
\hline Corn & 11.2 & 5.0 & 60.2 & 1.8 & 78.2 \\
\hline Cottonseed & 38.9 & - & 38.7 & - & 77.6 \\
\hline Olive & 11.9 & - & 0.7 & - & 12.6 \\
\hline Palm & 25.6 & - & 31.6 & 7.0 & 64.2 \\
\hline Peanut & 13.0 & 21.4 & 2.1 & - & 36.5 \\
\hline Safflower & 34.2 & - & 7.1 & - & 41.3 \\
\hline Sesame & 13.6 & - & 29.0 & - & 42.6 \\
\hline Sunflower & 48.7 & - & 5.1 & 0.8 & 54.6 \\
\hline Soya & 7.5 & 1.5 & 79.7 & 26.6 & 115.3 \\
\hline Walnut & 56.3 & - & 59.5 & 45.0 & 160.8 \\
\hline
\end{tabular}

It has been determined in various experimental studies that gamma tocopherol has an anti-inflammatory effect by inhibiting cyclooxygenase-2 (COX-2), but that at the same dose alpha tocopherol has no effect (Ohrvall et al., 1996; Huang and Appel, 2003).

\section{Conclusions}

Fig seed oil (Ficus carica), contains both omega- 3 and omega- 6 unsaturated fatty acids in high proportions. At the same time, it has a high proportion of the gamma tocopherol form of vitamin $E$, the benefits of which have recently been understood, making it a very valuable and unequalled source. Analysis has shown it to contain a much higher proportion of gamma tocopherol than many other plant and seed sources.

Since the flesh of the figs is washed continuously and repeatedly with water and the seeds are obtained, possible aflatoxin accumulation is also washed. It can also be used to obtain oil in the kernels obtained from old figs that have waited and have increased possible aflatoxin. On the other hand, in the process of obtaining the seeds, purification from fungi or toxins takes place due to continuous washing in water. Therefore, no aflatoxin was detected in the oil obtained. Figs that are economically outdated or contain high aflatoxin are generally destroyed. With this process, it will be possible to bring them into the economy as fig seed oil.

Obtaining omega-3 from a plant source, the oil of the seeds of figs rather than seafoods, brings with it some advantages in use. It is reliable from the point of view of the heavy metals that seafoods may contain. Rather than having a fishy smell, it smells more of cocoa, making it easier to use especially with children. This opens up a new use for figs which have spoiled or which have been discarded for culinary use but which do not contain aflatoxins.

The fact that fig seed oil is rich in omega- 3 and gamma tocopherol will allow its use in cosmetic products and health industry. The fact that it is rich in gamma tocopherol and the positive effects of gamma tocopherol more than alpha on human health in recent years will open a new window of opportunity for Turkey, which has a weight in fig production. 
Author Contributions: S.Tarlacı have designed the study, collected the data, executed the experiments and wrote the article.

\section{Conflict of interests: The authors declare that for} this article they have no actual, potential or perceived the conflict of interests.

\section{References}

Alinafiah, S.A., Azlan, A., Ismail, A and Rashid, N.K. (2021). Method Development and Validation for Omega-3 Fatty Acids (DHA and EPA) in Fish Using Gas Chromatography with Flame Ionization Detection (GCFID). Molecules, 26(21), 6592

Badgujar, S. B., Patel, V. V., and Bandivdekar, A. H. (2014). Traditionaluses. Phytochemistry and Pharmacology of Ficus carica: A Review. Pharmaceutical Biology, 52 (11), 1487-503

Campbell, S.E., Stone, W.L., Whaley, S.G., Qui, M., Krishnan, K. (2003). Gamma tocopherol upregulates peroxisome proliferator activated receptor (PPAR) gamma expression in SW 480 human colon cancer cell lines. BMC Cancer, 1, 3:25.

Güven, N., Gökyer, A., Koç, A., Temiz, N.N. (2019). Physiochemical Composition of Fig Seed Oil from Turkey. Journal of Pharmacy and Pharmacology, 7, 541-545

Hernandez, L.M., Wu, X., Lin, J., Radcliffe, J.D. (2004). Intake of vitamin $E$ (2-R isomers of alpha-tocopherol) and gamma-tocopherol in a case-control study and bladder cancer risk. Proc Amer Assoc Cancer Res, 45,904.

Huang, H.Y., Appel, L.J. (2003). Supplementation of diets with alpha-tocopherol reduces serum concentrations of gamma- and delta-tocopherol in humans. J Nutr, 133(10), 3137-40.

Hunter, J.E., Zhang, J., Kris-Etherton, P.M. (2009). Cardiovascular disease risk of dietary stearic acid compared with trans, other saturated, and unsaturated fatty acids: A systematic review. American Journal of Clinical Nutrition, 91 (1), 46-63.

Joseph, B., and Raj, S. J. (2011). Pharmacognostic and Phytochemical Properties of Ficus carica Linn-An Overview. International Journal of Pharm Tech Research, 3, (1), 8-12.

Khanna, S., Roy, S., Slivka, A., Craft, T.K., Chaki, S., Rink, C., Notestine, M.A., DeVries, A.C., Parinandi, N.L., Sen, C.K. (2005). Neuroprotective properties of the natural vitamin E a-tocotrienol. Stroke, 36, e144-e152.

Kingsbury, K.J., Paul, S., Crossley, A., Morgan, D.M. (1961).
The fatty acid composition of human depot fat. Biochemical Journal, 78, 541-550.

Mawa, S., Husain, K., \& Jantan, I. (2013). Ficus carica L.(Moraceae): phytochemistry, traditional uses and biological activities. Evidence-Based Complementary and Alternative Medicine, Article ID 974256

Nada, A. (2011). In vitro and in vivo permeation of vitamin $E$ and vitamin $\mathrm{E}$ acetate from cosmetic formulations. Med Princ Pract, 20, 509-13.

NAL, The National Agricultural Library. ndb.nal.usda.gov/ndb/foods/show/2250 National Nutrient Database for Standard Reference. (accessed date: June 6, 2020)

Ohrvall, M., Sundlöf, G., Vessby, B. (1996). Gamma, but not alpha, tocopherol levels in serum are reduced in coronary heart disease patients. J Intern Med, 239(2), 111-7.

Qureshi, A.A., Bradlow, B.A., Brace, L., Manganello, J., Peterson, D.M., Pearce, B.C., Wright, J.J., Gapor, A., Elson, C.E. (1995). Response of hypercholesterolemic subjects to administration of tocotrienols. Lipids, 30(12), 1171-1177.

Senyilmaz, D., Virtue, S., Xu, X., Tan, C.Y., Griffin, J.L., Miller, A.K., Vidal-Puig, A., Teleman, A.A. (2015). Regulation of mitochondrial morphology and function by stearoylation of TFR1. Nature, 525: 124-128.

Siger, A., Nogala-Kalucka, M., Lampart-Szczapa, E. (2008). The Content and Antioxidant Activity of Phenolic Compounds in Cold-Pressed Plant Oils. Journal of Food Lipids. 15 (2): 137-149.

Simopoulos, A.P. (2002). The importance of the ratio of omega-6/omega-3 essential fatty acids. Biomed Pharmacother, 56(8), 365-79.

Simopoulos, A.P. (2006). Evolutionary aspects of diet, the omega-6/omega-3 ratio and genetic variation: nutritional implications for chronic diseases. Biomed Pharmacother, 60(9), 502-7.

Simopoulos, A.P. (2010). Genetic variants in the metabolism of omega- 6 and omega- 3 fatty acids: their role in the determination of nutritional requirements and chronic disease risk. Exp Biol Med, 235(7), 785-95.

Singh, I., Carey, A.L., Watson, N., Febbraio, M.A., Hawley, J.A. (2008). Oxidative stress-induced insulin resistance in skeletal muscle cells is ameliorated by gammatocopherol treatment. Eur J Nutr, 47(7),387-92.

Whitney, E., Rolfes, S.R. (2008). Understanding Nutrition (11th ed.). California: Thomson Wadsworth, p.154.

WHO Technical Report Series, 916. Diet, Nutrition and the Prevention of Chronic Diseases. Report of a Joint WHO/FAO Expert Consultation, World Health Organization, Geneva, 2003, p.88, Table 10. 